\title{
MIR92A1 Pre-miRNA
}

National Cancer Institute

\section{Source}

National Cancer Institute. MIR92A1 Pre-miRNA. NCI Thesaurus. Code C82737.

MIR92A1 pre-miRNA is an oligoribonucleotide that is encoded by the human MIR92A1 gene and is involved in the regulation of gene expression. 